\title{
Properties of amorphous FeCoB alloy particles (abstract)
}

\section{Charles, S. W.; Wells, S.; Meagher, A.; Mørup, Steen; Van Wonterghem, J.}

\section{Published in:}

Journal of Applied Physics

Link to article, DOI:

$10.1063 / 1.342317$

Publication date:

1988

Document Version

Publisher's PDF, also known as Version of record

Link back to DTU Orbit

Citation (APA):

Charles, S. W., Wells, S., Meagher, A., Mørup, S., \& Van Wonterghem, J. (1988). Properties of amorphous FeCoB alloy particles (abstract). In Journal of Applied Physics (Vol. 64/10). American Institute of Physics. https://doi.org/10.1063/1.342317

\section{General rights}

Copyright and moral rights for the publications made accessible in the public portal are retained by the authors and/or other copyright owners and it is a condition of accessing publications that users recognise and abide by the legal requirements associated with these rights.

- Users may download and print one copy of any publication from the public portal for the purpose of private study or research.

- You may not further distribute the material or use it for any profit-making activity or commercial gain

- You may freely distribute the URL identifying the publication in the public portal

If you believe that this document breaches copyright please contact us providing details, and we will remove access to the work immediately and investigate your claim 


\section{Properties of amorphous FeCoB alloy particles (abstract)}

S. W. Charles, S. Wells, and A. Meagher

Department of Physics, University College of North Wales, Bangor, Guynedd, United Kingdom

S. Mørup and J. van Wonterghem

Laboratory of Applied Physics II, Technical University of Denmark DK-2800, Lyngby, Denmark

Amorphous and crystalline alloy particles $(0.05-0.5 \mu \mathrm{m})$ of $\mathrm{Fe}_{x} \mathrm{Co}_{y} \mathrm{~B}_{z}$ in which the ratio $y x$ ranges from 0 to 0.1 have been prepared by the borohydride reduction of iron and cobalt salts in aqueous solution. The structure of the particles has been studied using Mössbauer spectroscopy and $x$-ray diffraction. Magnetic measurements of the saturation magnetization, coercivity, and remanence of the particles have been measured. The transition from the amorphous-to-crystalline state has been studied using differentiai scanning calorimetry (DSC) and thermomagnetometry up to a temperature of $450^{\circ} \mathrm{C}$ (see Fig. 1). It has been shown that the fraction of boron in the alloys $(10-35$ at. $\%)$ is dependent upon the rate of addition of saits to borohydride and the concentration of cobalt present; this in tum influences the crystallinity and magnetic properties .

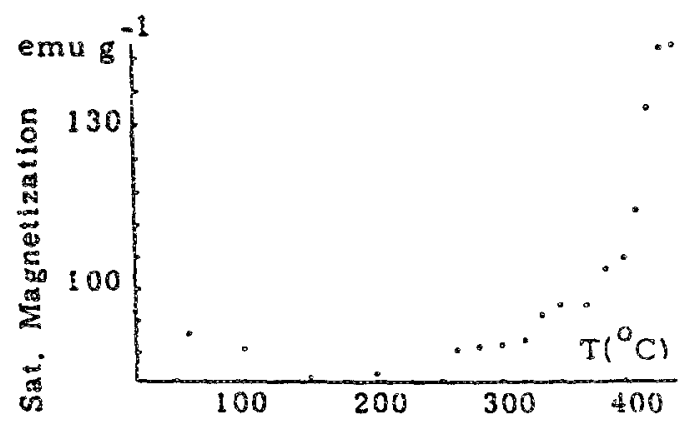

FIG. 1. 